\title{
PENINGKATAN EFISIENSI PROSES PEWARNAAN MELALUI PEMBERIAN AGEN FIKSASI RAMAH LINGKUNGAN PADA KELOMPOK BATIK TULIS PASURUAN
}

\author{
Oleh:

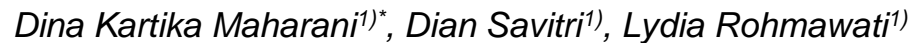 \\ ${ }^{1}$ FMIPA Universitas Negeri Surabaya \\ *dinakartika@unesa.ac.id \\ Abstrak
}

\begin{abstract}
Batik Indonesia telah ditentukan sebagai salah satu warisan dunia oleh Unesco. Pengembangan inovasi proses produksi batik tulis meliptui proses pewarnaan dan desain motif merupakan faktor penting untuk meningkatkan penjualan dan kapasitas produksi. Kota Pasuruan memiliki produksi batik khas yang dikenal dengan batik sirih kelor. Batik Pasuruan belum populer di kalangan masyarakat, sehingga pelatihan dan pendampingan terkait proses pewarnaan dan desain motif perlu dilakukan. Pelatihan yang dilakukan terhadap kelompok mitra batik pasuruan meliputi pelatihan penggunaan agen fiksasi ramah lingkungan pada proses pewarnaan serta penggunaan alat padder untuk meningkatkan kapasitas produksi dan efisiensi waktu produksi.
\end{abstract}

Kata Kunci: batik, warna, agen fiksasi, ramah lingkungan

\begin{abstract}
Indonesian Batik is determined as a world heritage by Unesco. Development on batik production processes inovation including dyeing process and pattern design become one of important factors that increase selling and production. Pasuruan city has unique batik product namely sirih kelor batik. The product is less popular among others batik from different city, so training on dyeing process and pattern design are essential to do. The training for batik tulis group partner included introduction of eco friendly fixation agent for dyeing process and use of padder tools to improve efficiency of dye coating process. The result of the training showed that the uses of new fixation agent and padder tool increase the production capacity and improve time eficiency of batik production
\end{abstract}

Keywords: batik, dyes, fixation agent, eco-friendly

\section{PENDAHULUAN}

Batik Indonesia telah ditetapkan sebagai warisan kemanusiaan dan kebudayaan dunia oleh Unesco sejak tahun 2009. Di Pulau Jawa sendiri terdapat beragam jenis batik dengan corak khas sesuai asal daerahnya masing- masing, tidak terkecuali dengan kota Pasuruan yang juga memiliki batik khas dengan corak daun sirih dan burung kepodang. Meski terbilang masih tertinggal dengan daerah lain yang lebih dikenal akan motif batiknya terus berusaha meningkatkan kreasi dan desain motif batik. Dengan dukungan pemerintah kota Pasuruan yang terus mendorong terciptanya berbagai desain bentuk, motif, warna batik dan kombinasinya serta penetapan batik Pasuruan sebagai ciri khas kota Pasuruan menjadikan batik tulis khas kota Pasuruan ini sebagai peluang industri yang sangat menjanjikan. Berdasarkan hal tersebut, terlihat besarnya potensi batik tulis khas kota Pasuruan untuk dikembangkan dari segi kualitas produk terkait proses pewarnaan, desain motif, maupun peningkatan kapasitas produksi dan sistem pemasarannya. Namun, kelompok batik yang ada di Pasuruan jarang menggunakan pewarna alami mereka lebih memilih pewarna kimia. Faktanya di luar negeri tekstil dengan pewarna kimia dilarang karena dapat menyebabkan kanker kulit sehingga konsumen luar negeri suka batik yang memakai pewarna organik. Keterbatasan pengetahuan pengrajin batik tentang teknik pewarnaan menggunakan zat warna alami dengan cara fiksasi yang tepat menjadi persoalaan yang dihadapi oleh kedua mitra kelompok usaha batik ketika ingin mengembangkan batik tulis dengan bahan pewarna alami yang bernilai jual tinggi.

Salah satu kendala pewarnaan kain batik (mori) menggunakan zat warna alam adalah variasi warnanya sangat terbatas dan ketersediaan bahannya yang tidak siap pakai sehingga diperlukan proses-proses khusus untuk dapat dijadikan larutan pewarna mori. Oleh karena itu zat warna alam dianggap 
kurang praktis penggunaannya. Selain itu karena terbuat dari bahan-bahan alami, pewarna alami relatif tidak seawet pewarna kimia. Hal ini menyebabkan warna batik cenderung cepat memudar jika dicuci dengan detergen biasa. Namun dibalik kekurangannya tersebut zat warna alam memiliki potensi pasar yang tinggi sebagai komoditas unggulan produk Indonesia memasuki pasar global dengan daya tarik pada karakteristik yang unik, etnik dan eksklusif.

Untuk mengatasi hal tersebut di atas maka perlu upaya penyelesaian terkait proses pewarnaan batik yaitu dengan cara pemberian agen fiksasi untuk zat warna alami. Beberapa cara fiksasi sebagai penguat warna atau ada yang menyebut pengunci warna, supaya warna tidak luntur dan menempel kuat pada kain / media batik dicelup kedalam larutan alkali atau asam seperti asam klorida atau asam sulfat. Namun kedua jenis asam tersebut sangat berbahaya bagi lingkungan dan bersifat toksik. Apabila kontak dengan kulit akan iritasi ringan dan mudah melepuh atau rasa gatal pada kulit (Trismawati, dkk., 2010). Apabila terhirup menyebabkan terpapar diparu-paru dan akan menyebabkan nafas terasa sesak atau sakit di ulu hati. Setelah kontak dengan mata akan menyebabkan iritasi ringan. Sisa larutan fiksasi dengan asam klorida $(\mathrm{HCl})$ juga berpotensi menjadi limbah cair yang berbahaya bagi lingkungan, maka air sisa fiksasi perlu diolah ke dalam IPAL (Instalasi Pengolahan Air Limbah). Untuk mengatasi hal tersebut di atas maka perlu alternatif lain sebagai agen fiksasi yang lebih ramah lingkungan. Material biopolimer kitosan dan material $\mathrm{ZnO}$ merupakan salah satu agen fiksasi yang bersifat ramah lingkungan serta memiliki performa yang baik untuk meningkatkan ketahanan luntur zat warna pada batik (Fouda, 2005). Kedua material tersebut dapat digunakan sebagai pengganti agen fiksasi yang bersifat toksik dan berbahaya bagi lingkungan seperti $\mathrm{HCl}$. Proses pewarnaan juga dapat ditunjang oleh penggunaan alat padder untuk meningkatkan keseragaman pencelupan zat warna serta meningkatkan efektivitas dan efisiensi proses pewarnaan. Selama ini kelompok usaha batik tulis di Pasuruan belum menggunakan alat tersebut karena harganya relatif mahal.

Oleh karena itu dalam kegiatan pengabdian ini akan dilakukan kegiatan pelatihan dan pendampingan kepada kedua mitra kelompok usaha batik tulis Suryandaru dan Dahlia tentang konsep teknik pewarnaa menggunakan agen fiksasi ramah lingkungan, serta peningkatan efektivitas produksi menggunakan alat padder.

\section{METODE PELAKSANAAN}

Metode pelaksanaan IbM yang dilakukan meliputi tahapan-tahapan kegiatan sebagai berikut :

a. Kegiatan penyuluhan tentang pewarna alam dan sintetis untuk batik melalui metode ceramah dan diskusi dan pemberian modul materi penyuluhan.

b. Kegiatan penyuluhan tentang penggunaan agen fiksasi ramah lingkungan pada proses pewarnaan batik serta alat padder untuk meningkatkan ketahanan luntur pewarna alam maupun sintetis melalui metode ceramah dan diskusi dan pemberian modul materi penyuluhan.

c. Kegiatan pelatihan dan pendampingan teknik pewarnaan batik menggunakan agen fiksasi ramah lingkungan serta alat padder melalui uji coba atau praktek serta diskusi.

d. Monitoring dan evaluasi tentang keterlaksanaan kegiatan pelatihan melalui penilaian menggunakan lembar observasi kegiatan pelatihan.

e. Monitoring dan evaluasi tentang tanggapan peserta tentang pelatihan teknik pewarnaan, proses finishing serta perancangan desain motif dalam proses produksi batik tulis melalui penilaian menggunakan lembar angket respon peserta.

\section{HASIL DAN PEMBAHASAN}

Pelaksanaan pelatihan proses pewarnaaan menggunakan agen fiksasi diikuti oleh kedua mitra kelompok pengrajin batik tulis Suryandaru dan kelompok pengrajin batik tulis Dahlia. Selama ini proses pewarnaan batik tulis pada kedua kelompok mitra masih menggunakan agen fiksasi yang tidak ramah lingkungan seperti asam kuat $\mathrm{HCl}$ atau air accu yang juga menyebabkan gangguan pernafasan. Oleh karena itu, dalam kegiatan IbM ini dikenalkan agen fiksasi yang lebih ramah lingkungan salah satunya menggunakan Kitosan. Kitosan merupakan bahan biopolimer atau polimer alami yang memiliki sifat non toksik, biodegradable serta memiliki kemampuan sebagai agen fiksasi zat warna maupun sifat-sifat lain seperti anti bakteri dan anti luntur. Kitosan memiliki 
gugus fungsi $\mathrm{OH}$ dan $\mathrm{NH}_{2}$ yang dapat berikatan dengan baik dengan zat pewarna maupun dengan serat selulosa melalui interaksi elektrostatik maupu ikatan hidrogen. Hal ini mengakibatkan kitosan dapat digunakan sebagai agen fiksasi hampir pada semua zat warna.

Penggunaan kitosan sebagai agen fiksasi pada proses pewarnaan batik tulis ini merupakan terobosan baru dalam rangka menghasilkan batik tulis yang memiliki nilai tambah dan nilai ekonomi tinggi serta mendukung proses pelestarian lingkungan melalui pengurangan penggunaan bahanbahan kimia yang beracun dan merusak lingkungan.

Tahap pelatihan penggunaan agen fiksasi kitosan pada proses pewarnaan diawali dengan pemaparan tentang jenis-jenis agen fiksasi yang dapat digunakan dalam proses pewarnaan kemudian dilanjutkan dengan kegiatan diskusi dan tanya jawab tentang agen fiksasi pada proses pewarnaan batik tulis. Tahap selanjutnya yaitu tahap proses uji coba penggunaan agen fiksasi kitosan pada proses pewarnaan batik tulis pada mitra batik. Proses penambahan kitosan sebagai agen fiksasi dilakukan setelah proses pencelupan zat warna pada kain batik tulis. Hal ini bertujuan untuk memantapkan ikatan antara zat warna dengan kain terlebih dahulu selanjutnya zat warna pada kain dimantapkan ikatannya kembali dengan adanya kitosan.

Pelaksanaan pelatihan proses pewarnaaan menggunakan alat padder diikuti oleh kedua mitra kelompok pengrajin batik tulis Suryandaru dan kelompok pengrajin batik tulis Dahlia. Selama ini industri kecil batik atau home industri batik belum menggunakan alat padder dalam proses pewarnaan karena harganya relatif mahal dan menambah waktu proses pewarnaan, demikian juga yang terjadi di kelompok mitra pengrajin batik tulis Suryandaru dan Dahlia. Pelatihan penggunaan alat padder sederhana kepada kedua mitra kelompok pengrajin batik tulis Suryandaru dan kelompok pengrajin batik tulis Dahlia ini bertujuan untuk mengefektifkan proses penempelan warna pada kain sehingga dapat menghasilkan kain batik tulis yang bagus. Penggunaan alat padder ini dapat meningkatkan efisiensi waktu serta efektivitas proses pewarnaan pada pembuatan batik tulis maupun pada proses pengeringan. Sebelum menggunakan alat padder, proses pewarnaan yaitu proses pencelupan kain batik ke dalam zat warna membutuhkan waktu yang cukup lama serta dilakukan berulang-ulang dua sampai tiga kali. Hal ini berdampak pada waktu produksi kain batik tulis yang cukup lama. Dengan adanya alat padder, maka proses pencelupan kain batik ke dalam zat warna dapat dilakukan satu kali selanjutnya dimasukkan ke dalam alat padder untuk memantapkan ikatan antara kain dengan zat warna. Proses pengeringan kain batik tulis yang telah melalui tahap pewarnaan juga menjadi lebih singkat dengan adanya penggunaan alat padder ini. Rata-rata waktu yang dibutuhkan untuk menjemur kain batik tulis antara 8-10 jam, sedangkan waktu penjemuran kain batik setelah penggunaan alat padder berkurang menjadi 6-7 jam.
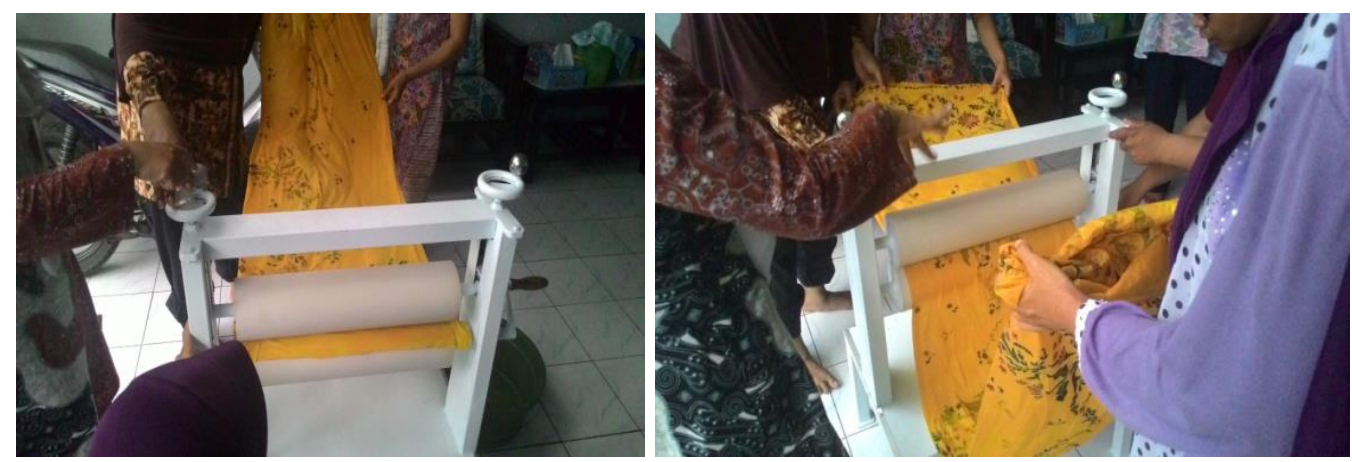

Gambar 1. Pelatihan menggunakan Alat Padder 

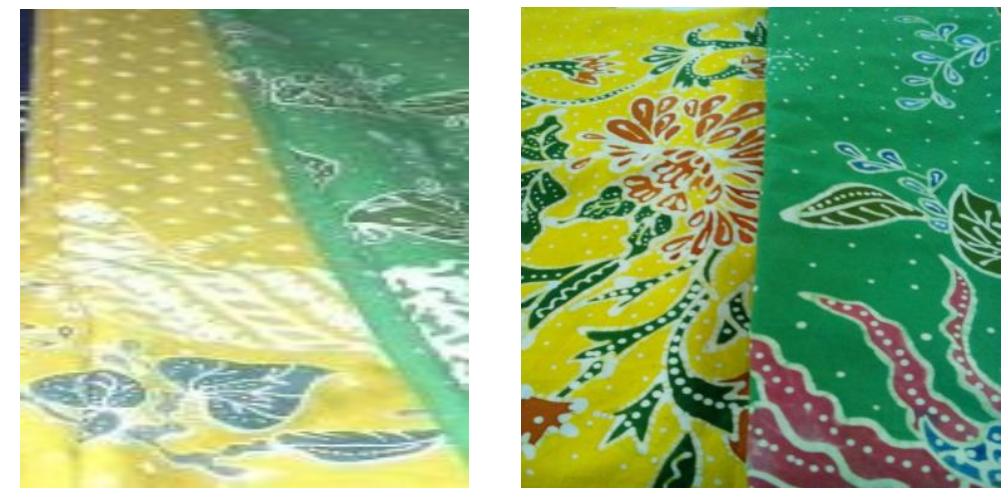

Gambar 2. Hasil Kain Batik Tulis Sebelum dan Sesudah Pengguanan Agen Fiksasi.

\section{SIMPULAN DAN SARAN}

Kesimpulan dalam kegiatan pengabdian ini kelompok usaha batik kota Pasuruan telah mengenal tentang adanya agen fiksasi kitosan yang ramah lingkungan serta penggunaan alat padder pada proses pewarnaan. Penggunaan agen fiksasi dapat meningkatkan nilai tambah dan nilai jual batik tulis. Efisiensi waktu dan efektivitas proses pewarnaan meningkat dengan adanya penggunaan alat padder pada proses akhir pewarnaan atau proses finishing

\section{DAFTAR PUSTAKA}

Fouda, M.M.G., 2005, Use of Polysacharides in Medical Textile Applications, Dissertation, Universitat Duissburgessen, Germany.

Herlina, S., 2015, Fiksasi bahan alami dari buah markisa dan jeruk nipis dalam proses pewarnaan batik dengan zat warna indigosol, Laporan penelitian, PPPTK Seni dan Budaya Yogyakarta
Peraturan Daerah Kota Pasuruan Nomor 11 Tahun 2003

Tim Pustaka JawaTimuran, 2009, Batik Jawa Timur, Aertikel dari koleksi Deposit No. 12.312/19-03-2010 - Badan Perpustakaan dan Kearsipan Provinsi Jawa Timur : ZONABIS, Media Informasi Kadin Wilayah Tengah, Volume II.

Tim Pustaka Jawa timuran, 2010, Batik Khas Kota Pasuruan, Artikel dari koleksi Deposit - Badan Perpustakaan dan Kearsipan Provinsi Jawa Timur: BANGKIT, Edisi IV, Tahun III.

Trismawati K., Setyabakti, V., Rosetyo, C.W., 2010, Pencelupan pada kain sutera menggunakan zat warna urang aring (Eclipta alba) dengan fiksator tawas, tunjung dan kapur tohor, Laporan PKMP, Universitas Negeri Yogyakarta 